Journal of Environmental Science and Sustainable Development

Volume 3

Issue 2 December

Article 7

$12-31-2020$

\title{
EFFECTS OF LEACHING ON THE RECLAMATION OF SALINE SOILS AS AFFECTED BY DIFFERENT ORGANIC AND INORGANIC AMENDMENTS
}

Sajal Roy

Department of Soil Science, Faculty of Biological Sciences, University of Chittagong, Chattogram-4331, Bangladesh, sajal.roy@cu.ac.bd

Nasrin Chowdhury

Department of Soil Science, Faculty of Biological Sciences, University of Chittagong, Chattogram-4331, Bangladesh, nasrin@cu.ac.bd

Follow this and additional works at: https://scholarhub.ui.ac.id/jessd

Part of the Agriculture Commons

\section{Recommended Citation}

Roy, Sajal and Chowdhury, Nasrin (2020). EFFECTS OF LEACHING ON THE RECLAMATION OF SALINE SOILS AS AFFECTED BY DIFFERENT ORGANIC AND INORGANIC AMENDMENTS. Journal of Environmental Science and Sustainable Development, 3(2), 329-354.

Available at: https://doi.org/10.7454/jessd.v3i2.1075

This Original Research Article is brought to you for free and open access by the School of Environmental Science at UI Scholars Hub. It has been accepted for inclusion in Journal of Environmental Science and Sustainable Development by an authorized editor of UI Scholars Hub. 


\title{
EFFECTS OF LEACHING ON THE RECLAMATION OF SALINE SOILS AS AFFECTED BY DIFFERENT ORGANIC AND INORGANIC AMENDMENTS
}

\author{
Sajal Roy*1, Nasrin Chowdhury ${ }^{1}$ \\ ${ }^{1}$ Department of Soil Science, Faculty of Biological Sciences, University of Chittagong, \\ Chattogram-4331, Bangladesh \\ ${ }^{*}$ Corresponding author: sajal.roy@cu.ac.bd
}

(Received: 19 October 2020; Accepted: 28 December 2020; Published: 31 December 2020)

\begin{abstract}
Soil salinity, which poses one of the greatest threats to sustainable crop production worldwide, can be ameliorated through various approaches, such as leaching, mulching, and amendment application. The effects of leaching and amendments on saline soil reclamation have been studied separately, but their interaction is poorly elucidated. Therefore, a column experiment was designed with soils that were subjected to leaching with 2 and 4 pore volume (PV) of water and compared with non-leached soils (NLS) to observe the effects of leaching on saline soil and leachate characteristics under different organic (vermicompost [VC] and wood ash [WA]) and inorganic (zeolite) amendments at two different rates $\left(1\right.$ and $\left.2 \mathrm{~g} 100 \mathrm{~g}^{-1}\right)$ and their combinations. Results revealed that the electrical conductivity $(\mathrm{EC})$ of the soil decreased, whereas the EC of the leachate increased as the PV of water increased. Regardless of the treatments, the concentrations of sodium $\left(\mathrm{Na}^{+}\right)$, potassium $\left(\mathrm{K}^{+}\right)$, calcium $\left(\mathrm{Ca}^{2+}\right)$, and magnesium $\left(\mathrm{Mg}^{2+}\right)$ in the leachate increased. By contrast, their concentrations in the leached soils decreased as the PV of water increased. WA contributed to a significant increase $(\mathrm{p}<0.01)$ in the EC and the concentrations of cations, especially $\mathrm{K}^{+}$and $\mathrm{Ca}^{2+}$, in the soils and leachates. The higher the rates of the amendment, the greater the increment in the EC and cation concentrations. Incorporating amendments could be important sources of cations, thereby limiting the entry of $\mathrm{Na}^{+}$into the exchange complex and facilitating leaching with percolating water. The response of spinach (Spinacia oleracea) in terms of yield parameters to $2 \mathrm{PV}$ of leached soils was significantly better than that of NLS, suggesting that soil leaching could significantly influence plant functioning in highly saline soils. This study suggested that the irrigation of saline soils under different organic and inorganic amendments before cultivation might affect salt leaching and soil nutrient dynamics, thereby influencing plant growth and yield.
\end{abstract}

Keywords: Amendments; Leaching; Pore volume; Reclamation; Soil salinity.

\section{Introduction}

Salt stress is one of the most significant abiotic stresses adversely affecting crop production (Alam, 1999; Gull et al., 2019; Roy \& Chowdhury, 2020a) and threatening global food security (Wicke et al., 2011). Salt-affected soils occupy more than $20 \%$ of agricultural lands worldwide (Etesami \& 
Noori, 2019; Khan \& Duke, 2001), especially in Asia, Australia, and South America, covering approximately more than 900 million hectares (Doula \& Sarris, 2016; Roy \& Chowdhury, 2020b; Wicke et al., 2011). Saline soils contain appreciable amounts of soluble salts of cations such as sodium $\left(\mathrm{Na}^{+}\right)$, calcium $\left(\mathrm{Ca}^{2+}\right)$, magnesium $\left(\mathrm{Mg}^{2+}\right)$, and potassium $\left(\mathrm{K}^{+}\right)$, together with anions such as chloride $\left(\mathrm{Cl}^{-}\right)$, sulfate $\left(\mathrm{SO}_{4}{ }^{2-}\right)$, carbonate $\left(\mathrm{CO}_{3}{ }^{2-}\right)$, and bicarbonate $\left(\mathrm{HCO}_{3}{ }^{-}\right)$; consequently, soil electrical conductivity (EC) is greater than $4 \mathrm{dS} \mathrm{m}^{-1}$ in saturated paste extract (Alam, 1999; Brady \& Weil, 2005; Hardie \& Doyle, 2012; Qadir et al., 2005).

In Bangladesh, more than 1.06 million hectares of land are affected by various degrees of soil salinity (SRDI, 2010). Most of the agricultural lands in coastal areas are not being utilized for crop production, mainly because of soil salinity, and the situation is expected to worsen due to climate change (Uddin, 2011). High salt concentrations in the root zone inhibit plant growth and yield by adversely affecting physiological and biochemical functions either through osmotic or nutritional imbalances (Roy \& Chowdhury, 2020a). The reclamation of saline soils has become increasingly important to enhance crop production worldwide. Saline soils can be effectively reclaimed by leaching salts, and this process requires a large amount of water. Over the years, leaching as an effective approach for the reclamation of salt-affected soils has been widely explored (Khoshgoftarmanesh et al., 2003; Mostafazadeh-Fard et al., 2008).

Leaching allows excess dissolved salts to move downward from the root zone with percolating water (Ayers \& Wescot, 1985; Harker \& Mikalson, 1990). However, removing salts from the root zone through leaching is often impractical in areas with water scarcity. Therefore, a minimum amount of water should be used to reduce the soil salinity so that crops can be cultivated sustainably.

Organic amendments have been widely studied for their astounding influences on physical, chemical, and biological properties (Ding et al., 2020; Leogrande \& Vitti, 2019; Roy et al., 2018; Roy \& Chowdhury, 2020a; Tejada et al., 2006). Improvements in soil physical properties, such as bulk density, aggregate stability, and permeability, can facilitate the leaching of soluble salts with percolating water. The application of organic amendments is effective in enhancing salt leaching, thereby reducing EC and improving the physical properties of salt-affected soils (Chaganti et al., 2015; Premanandarajah, 2017; Yue et al., 2016). The response of plants to vermicompost (VC) (Zhang et al., 2020), wood ash (WA) (Boh et al., 2013), and zeolite (Al-Busaidi et al., 2008) has also been studied in salt-affected soils.

Although the effects of leaching and amendment application in saline soils have been studied separately, their interaction is poorly understood. Moreover, the effect of WA alone or in 
combination with other organic amendments, such as VC, and inorganic amendments, such as zeolite, on the reclamation of acidic saline soils through leaching has not yet been studied. Thus, this research was conducted to observe the effects of leaching on the magnitude of the reclamation of saline soils under the individual and combined applications of two organic amendments, namely, VC and WA, and an inorganic amendment, namely, zeolite. Their interactions should be understood to assess nutrient turnover in saline soils crucial for their sustainable use and rehabilitation. Their interactions should also be explored because of climate change likely results in an increase in soil salinity in the southeastern part of Bangladesh, where soil salinity is a major constraint to sustainable crop production.

Therefore, this study provided insights into the appropriate measures for the restoration of saline soils through leaching in combination with applying different organic and inorganic amendments so that sustainable crop production in saline areas could be ensured. We hypothesized that the integrative leaching and amendment incorporation approaches would reduce soil salinity severity and increase nutritive values by supplying $\mathrm{K}^{+}$and $\mathrm{Ca}^{2+}$ in soils.

\section{Methods}

Soil-filled columns were subjected to 2 and 4 PV of water and compared with amended soils that were not subjected to leaching to observe the effectiveness of different volumes of water on the extent of salt leaching under different organic and inorganic amendments.

\subsection{Collection and processing of soil samples}

Bulk soil samples from a depth of 0-15 cm were collected from Anwara Upazila (N 22.151382 and E 91.840534) in Chattogram District in the southeastern part of Bangladesh. The soils in this area had a history of being previously cultivated and were abandoned without any crop cultivation for more than 15 years because of high salinity. They have a clay loam texture and belong to the Raozan soil series of the USDA soil taxonomy. The collected soil samples were crushed with a wooden hammer. Visible plant detritus and gravels were removed from the soil and then passed through stainless steel sieve with $2 \mathrm{~mm}$ openings and mixed thoroughly to obtain homogeneous samples. Subsamples were gathered randomly for the analysis of the physical and chemical parameters of the soils. 


\subsection{Collection and processing of amendments}

Cow dung vermicompost (hereinafter referred to vermicompost) and WA were used as organic amendments, and calcium-type zeolite $\left(\mathrm{CaAl}_{2} \mathrm{Si}_{4} \mathrm{O}_{12} \cdot \mathrm{nH}_{2} \mathrm{O}\right)$ was utilized as an inorganic amendment. Zeolite was collected from a market distributed by National Agricare, Indonesia. Vermicompost was collected from an organic farm and prepared by using earthworm Eisenia fetida (Amouei et al., 2017) to compost cow dung and banana plants (80:20, w/w). WA was prepared by burning woods in mud stoves. The organic amendments were passed through a $2 \mathrm{~mm}$ sieve.

\subsection{Leaching experiment setup}

A leaching experiment was conducted at the Department of Soil Science, University of Chittagong. The layout of the leaching experiment is shown in Figure 1. In this experiment, $200 \mathrm{~g}$ (on oven dry weight basis) of $2 \mathrm{~mm}$ sieved soil samples were weighed with an electric balance and placed on a

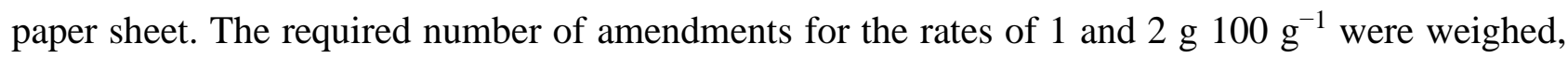
thoroughly mixed individually, and combined with the previously weighed soil samples, and placed in PVC tubes. After the soil and amendments were homogeneously mixed, the samples were placed in the PVC plastic tubes $(12 \mathrm{~cm}$ in height and $5 \mathrm{~cm}$ in diameter) in triplicates. Therefore, 13 treatments, including the control (without amendment), were prepared.

\section{T1: Control}

T2: Soil + VC (1 g $\left.100 \mathrm{~g}^{-1}\right)$

T3: Soil + WA (1 g $\left.100 \mathrm{~g}^{-1}\right)$

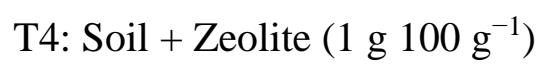

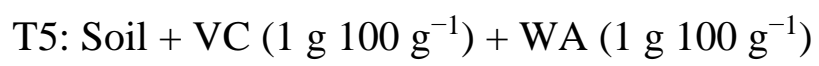

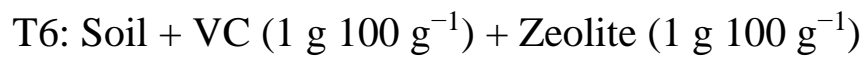

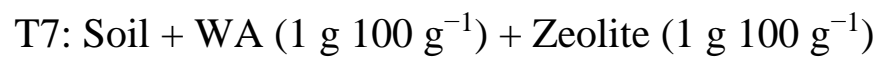

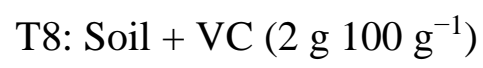

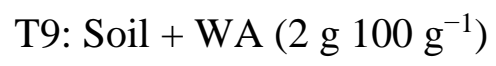

T10: Soil + Zeolite $\left(2{\left.\mathrm{~g} 100 \mathrm{~g}^{-1}\right)}^{-1}\right.$

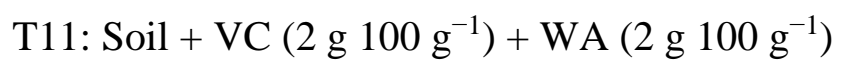

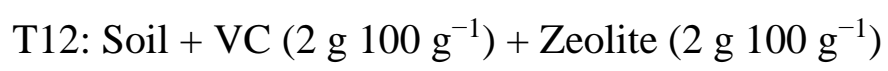

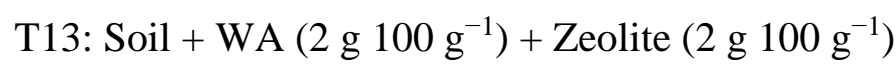


Soils were packed in such a way that a uniform bulk density $\left(1.13 \mathrm{~g} \mathrm{~cm}^{-3}\right)$ was maintained in all the soils (amended soils and control soil). The bottom of the cylinders was tightly sealed with a cotton cloth and rubber band. An initial amount of $20 \mathrm{~g}(\sim 0.5 \mathrm{~cm})$ of acid-washed sand was placed at the bottom of the tubes. Soils were leached with distilled water by 2 and 4 times of the PV. The PV was adjusted to $96 \mathrm{~cm}^{3}$ for all the soil columns. The PV of the soil column was calculated with the following formula (Kirkham, 2004):

$$
\mathrm{PV}=\mathrm{Vs} \times \Phi \mathrm{s},
$$

where Vs is the volume of the soil in the column, and $\Phi$ s is the porosity.

Soil-filled columns were initially subjected to wetting from the bottom. After complete saturation from the bottom occurred, the direction of the flow was kept in reverse order by constantly maintaining water at about $2 \pm 0.5 \mathrm{~cm}$ on top of the soil. Then, 192 and $384 \mathrm{~mL}$ of distilled water were passed through the soil column for 2 and $4 \mathrm{PV}$, respectively.

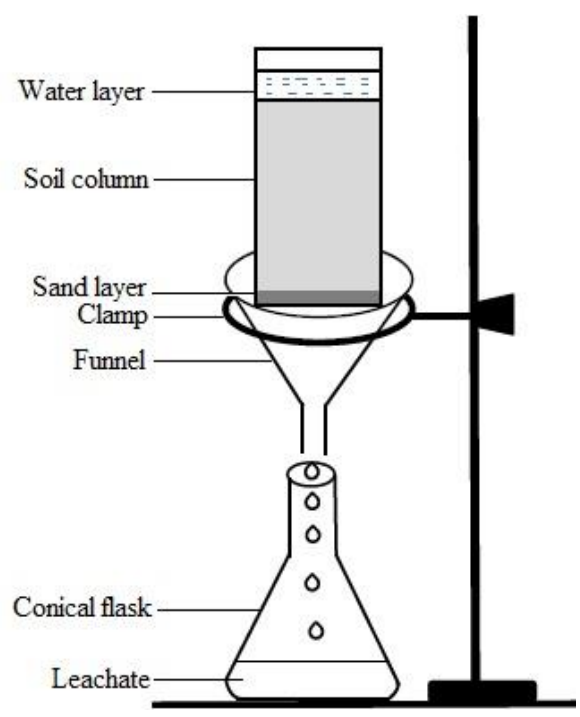

Figure 1. Layout of the experiment

The leachates were collected in a conical flask and analyzed in terms of $\mathrm{pH}, \mathrm{EC}, \mathrm{Na}^{+}, \mathrm{K}^{+}, \mathrm{Ca}^{2+}$, and $\mathrm{Mg}^{2+}$. After the water was completely leached, the soil samples were removed from the PVC tubes, air dried, and sieved through $2 \mathrm{~mm}$ openings. The leached and NLS samples were examined in terms of $\mathrm{pH}, \mathrm{EC}, \mathrm{Na}^{+}, \mathrm{K}^{+}, \mathrm{Ca}^{2+}$, and $\mathrm{Mg}^{2+}$.

\subsection{Cultivation of plants}

A trial pot experiment was conducted with spinach (Spinacia oleracea) in November 2019 to observe plants' growth at minimum irrigation levels of soils. Its seeds were individually sown in 
plastic pots containing $2 \mathrm{~kg}$ (on oven dry weight basis) of nonbleached and $2 \mathrm{PV}$ leached soils in triplicates. Recommended doses of N-P-K fertilizers were applied. In each pot, five plants could grow after germination with the necessary care. After 35 days of sowing, yield parameters such as the number of leaves, fresh weight, and height of shoots and roots were measured.

\subsection{Laboratory analysis}

Soil $\mathrm{pH}$ and EC were measured in the suspension prepared at a soil-to-water ratio of 1:5 (w/v). Organic amendments were measured at a ratio of organic matter to the water of 1:10 (w/v) (Yue et al., 2016) by using a glass electrode pH meter (Seven CompactTM pH/Ion S220) and an EC meter (Adwa AD 330). The soil sample's particle size was analyzed with a hydrometer (Huq \& Alam, 2005). The bulk density and particle density of the soil samples were determined with the core method (Wilke, 2005) and the pycnometer method (Ramulu, 2003), respectively. Organic carbon (OC) was determined with Walkley-Black wet oxidation method. Organic matter (OM) content was estimated indirectly by multiplying the OC content by the van Bemmelen factor of 1.724 (Nelson \& Sommers, 1982).

Cation exchange capacity (CEC) was determined by extracting the soil with $1 \mathrm{~N} \mathrm{NH}_{4} \mathrm{OAc}(\mathrm{pH}$ 7.0) and rinsed with ethyl alcohol; afterward, the adsorbed $\mathrm{NH}_{4}{ }^{+}$was replaced and determined (Chapman, 1965). Exchangeable $\mathrm{Na}^{+}$and $\mathrm{K}^{+}$were determined with an atomic absorption spectrometer (Agilent Technologies 200 Series AA), and exchangeable $\mathrm{Ca}^{2+}$ and $\mathrm{Mg}^{2+}$ were identified with the ethylene diamine tetraacetic acid method after the samples were extracted with 1 $\mathrm{N} \mathrm{NH}_{4} \mathrm{OAc}$ at $\mathrm{pH}$ 7.0. For the analysis of the total concentrations of the elements, $0.5 \mathrm{~g}$ of the sample was first digested from a starting temperature of $50^{\circ} \mathrm{C}$ to a final temperature of $350^{\circ} \mathrm{C}$ with a digestion mixture solution prepared by carefully adding $420 \mathrm{~mL}$ of concentrated $\mathrm{H}_{2} \mathrm{SO}_{4}$ with continuous swirling and cooling to $350 \mathrm{~mL}$ of $\mathrm{H}_{2} \mathrm{O}_{2}, 0.42 \mathrm{~g}$ of Se powder, and $14 \mathrm{~g}$ of $\mathrm{LiSO}_{4} \cdot \mathrm{H}_{2} \mathrm{O}$ (Parkinson \& Allen, 1975).

\subsection{Statistical analysis}

Duncan's multiple range test was performed using SPSS version 16 to determine the statistical differences between pairs of means. Correlation analyses were also conducted with the same software. Standard deviations were determined with Microsoft Excel 2010. 


\section{Results and Discussion}

The initial characteristics of the collected soil sample are given in Table 1. The soil texture was clay loam composed of $31 \%$ sand, $42 \%$ silt, and $27 \%$ clay. The collected soil sample was categorized to be extremely saline in terms of EC. WA contained the highest amounts of total $\mathrm{K}, \mathrm{Ca}$, and $\mathrm{Mg}$ of all the amendments.

Table 1. Physicochemical properties of soil and amendments

\begin{tabular}{lcccc}
\hline Parameters & Soil & Zeolite & VC & WA \\
\hline $\mathrm{pH}$ & 5.22 & 7.47 & 7.89 & 11.77 \\
$\mathrm{EC}\left(\mathrm{mS} \mathrm{cm}^{-1}\right)$ & 4.38 & 3.09 & 1.92 & 11.27 \\
$\mathrm{OC}(\%)$ & 1.11 & 0.17 & 18.06 & 0.17 \\
$\mathrm{OM}(\%)$ & 1.91 & 0.29 & 31.14 & 0.29 \\
Bulk density $\left(\mathrm{g} \mathrm{cm}^{-3}\right)$ & 1.22 & - & - & - \\
Particle density $\left(\mathrm{g} \mathrm{cm}^{-3}\right)$ & 2.49 & - & - & - \\
CEC $\left.(\mathrm{Cmol} \mathrm{kg})^{-1}\right)$ & 34.49 & - & - & - \\
Total Na $(\%)$ & 0.67 & 0.47 & - & 0.11 \\
Total K $(\%)$ & 2.17 & 1.81 & 2.34 & 4.13 \\
Total Ca $(\%)$ & 0.31 & 3.04 & 2.56 & 10.40 \\
Total $\mathrm{Mg}(\%)$ & 0.63 & 0.88 & 0.42 & 1.28 \\
\hline
\end{tabular}

\section{1. pH of soils and leachates}

The $\mathrm{pH}$ of soils treated with different amendments and the control without leaching and after leaching is shown in Figure 2a. The $\mathrm{pH}$ of the soils treated with the amendments was high. Among the treatments, WA had the highest responses, whereas VC and zeolite had the lowest responses. The $\mathrm{pH}$ increased and differed significantly $(\mathrm{p}<0.01)$ when WA was incorporated either alone or in combination with other amendments. Under NLS, 2 PV, and 4 PV leached conditions, the pH in T9 increased by $45.10 \%, 46.11 \%$, and $33.54 \%$ compared with that of T1, respectively. Similarly, the second-highest response of soil $\mathrm{pH}$ to amendments was observed in $\mathrm{T} 3$. The increments of soil $\mathrm{pH}$ in nonleached, $2 \mathrm{PV}$, and $4 \mathrm{PV}$ leached soils were $37.62 \%, 37.20 \%$, and $29.53 \%$ in T3 compared to $\mathrm{T} 1$, respectively. Conversely, treatment $\mathrm{T} 2$ resulted in the lowest soil $\mathrm{pH}$ response, i.e., $3 \%$ and $6 \%$ higher than that of the T1 in the nonleached and 2 PV leached soils. In 4 PV leached soils, pH in T6 and $\mathrm{T} 8$ increased by $7 \%$ compared with that of $\mathrm{T} 1$. 
Soil pH was significantly higher $(\mathrm{p}<0.01)$ in $2 \mathrm{PV}$ and 4 PV leached soils in all the treated soils than in the NLS. The leaching of soils with $2 \mathrm{PV}$ of water caused a minimum of $0.66 \% \mathrm{pH}$ increase in $\mathrm{T} 1$ and $6.32 \% \mathrm{pH}$ increase in $\mathrm{T} 8$, whereas $4 \mathrm{PV}$ leaching resulted in a $9.69 \%$ increase in $\mathrm{pH}$ in $\mathrm{T} 11$ and $32.17 \%$ increase in $\mathrm{pH}$ in $\mathrm{T} 2$. These values were higher than those in the NLS. Furthermore, $4 \mathrm{PV}$ leaching increased the soil $\mathrm{pH}$ from $8.62 \%$ in $\mathrm{T} 11$ to $26.86 \%$ in $\mathrm{T} 2$ compared with that in $2 \mathrm{PV}$ leaching.

The leachates' $\mathrm{pH}$ increased when the soils were treated with WA either separately or in combination, and the variations in the treatments with 2 and 4 PV leachates were statistically significant ( $\mathrm{p}<0.01$; Figure $2 \mathrm{~b}$ ). The highest $\mathrm{pH}$ of the leachates was observed in T9, i.e., their $\mathrm{pH}$ was $16.65 \%$ and $14.97 \%$ higher than that in the soils without amendments under 2 and $4 \mathrm{PV}$ conditions. On the contrary, the $\mathrm{pH}$ of the leachate of $\mathrm{T} 1$ was the lowest under both leaching conditions.

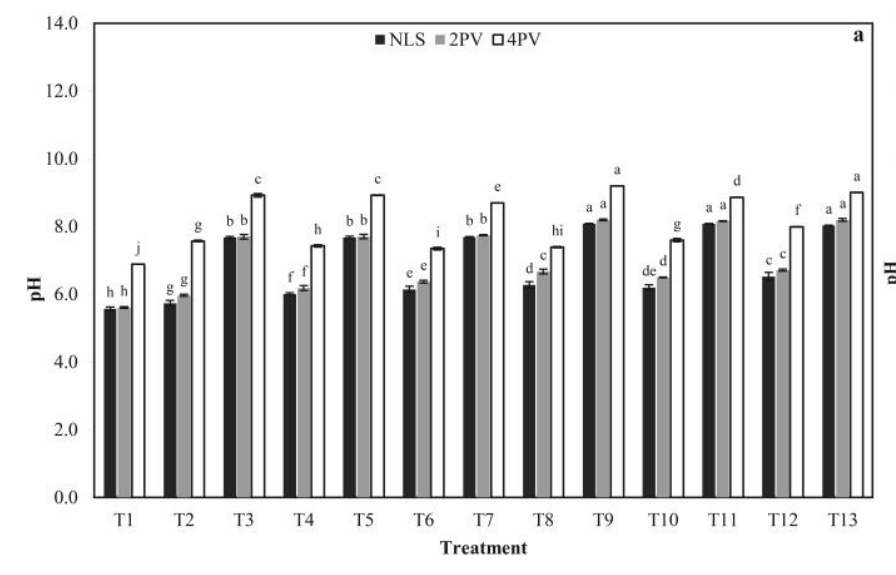

(a)

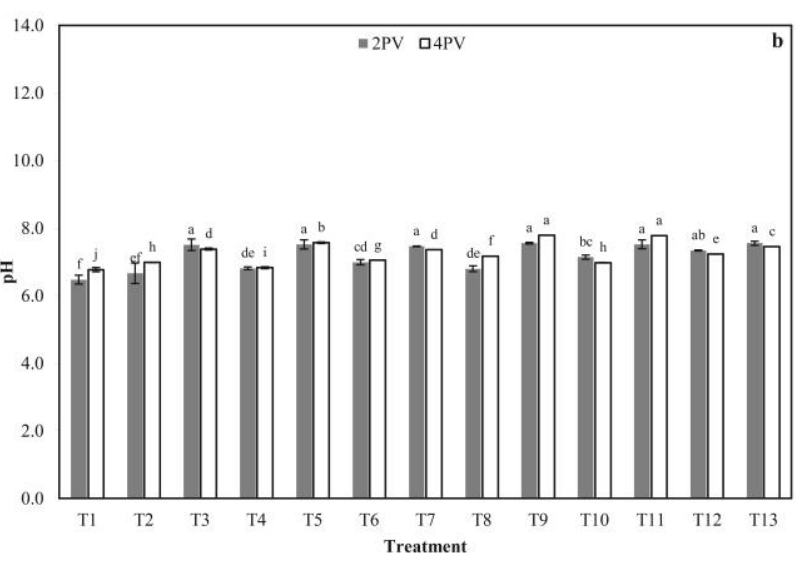

(b)

Figure 2. pH of (a) soils and (b) leachates under different treatments. Means followed by the same letter (s) among the same-colored bars did not differ significantly from each other at 5\% significance level

\subsection{EC of soils and leachates}

The EC of the nonleached and leached soils treated with different amendments are shown in Figure 3a. Regardless of the leaching conditions, the EC of all the treated soils was significantly higher than that of control $(\mathrm{p}<0.01)$. The EC of the soil treated with WA either alone or in combination was higher than that of the soil with other treatments. The higher the rate, the higher the EC. Conversely, the EC of NLS slightly increased after the addition of $\mathrm{VC}$ alone or in combination at 1

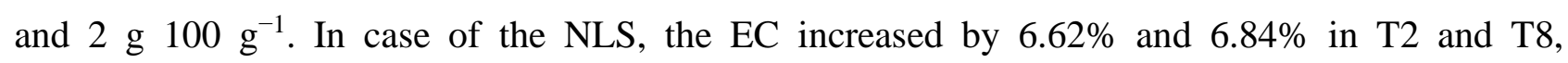
respectively in comparison to T1. By comparison, the soil EC increased by $9.07 \%$ and $12.57 \%$ in T3 and T9, respectively. 
However, the soil EC was significantly reduced by leaching compared with that in the NLS (p < 0.01). In T1, EC decreased by $12.42 \%$ and $91.57 \%$ because of the leaching of 2 and 4 PV of water compared with that of NLS. When soils were subjected to leaching with 2 PV, EC decreased from the lowest value of $5.58 \%$ to the highest value of $25.50 \%$. By contrast, EC decreased from a minimum of $86.15 \%$ to a maximum of $93.35 \%$ in the case of $4 \mathrm{PV}$ of water leaching. When $4 \mathrm{PV}$ of water was passed through the soils, the maximum decrease (i.e., 93.35\%) in EC was found in T2.

The EC of leachates is shown in Figure 3b. The leachate EC significantly differed $(\mathrm{p}<0.01)$ when the soils treated with amendments were subjected to leaching with 2 or $4 \mathrm{PV}$ of water. The EC of the leachates were high at high rates of incorporation either individually or in combination. The EC was $74.92 \%$ higher in T11 than that of T1 because of 2 PV of water leaching. By contrast, a maximum EC of $35.39 \%$ was observed in T9 compared to T1 under 4 PV of water leaching.

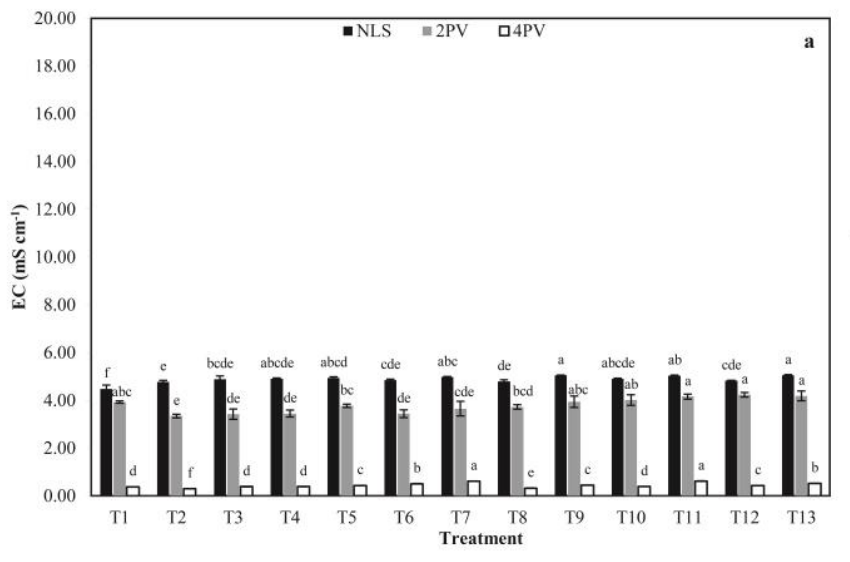

(a)

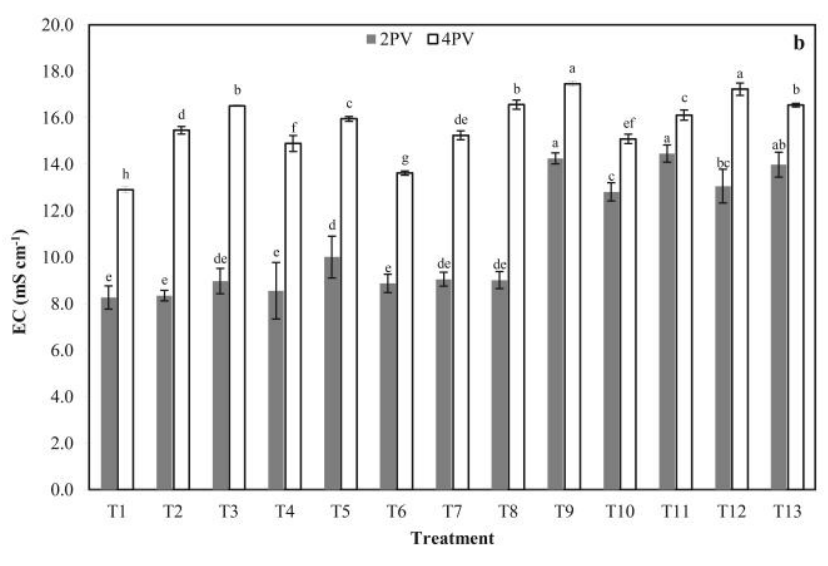

(b)

Figure 3. $\mathrm{EC}\left(\mathrm{mS} \mathrm{cm}^{-1}\right)$ of (a) soils and (b) leachates under different treatments. Means followed by the same letter (s) among the same-colored bars did not differ significantly from each other at 5\% significance level

\subsection{The concentration of $\mathrm{Na}^{+}$in soils and leachates}

In general, under the leached and non-leached conditions, the lowest concentration of $\mathrm{Na}^{+}$was observed in VC-amended soils, whereas the highest content was found in zeolite-incorporated soils

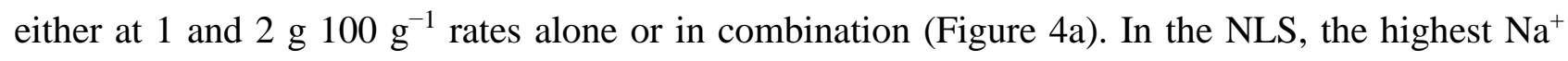
concentration was observed in T10. When soils were leached with $2 \mathrm{PV}$, the maximum $\mathrm{Na}^{+}$ concentration was found in T13. However, no significant difference $(\mathrm{p}>0.05)$ in the $\mathrm{Na}^{+}$ concentration was observed in all the treated soils and T1 in the non-leached, and 2 PV leached soils. Conversely, the highest $\mathrm{Na}^{+}$content was detected in $\mathrm{T} 1$, and the $\mathrm{Na}^{+}$concentration in all the treatments was significantly lower $(\mathrm{p}<0.01)$ in 4 PV leached soils. In the NLS, incorporating the amendments except for $\mathrm{T} 2$ and $\mathrm{T} 8$ resulted in an increase in the $\mathrm{Na}^{+}$concentration from a minimum 
of $0.08 \%$ in T6 to a maximum of $5.72 \%$ in T13 compared with that of T1. The concentration of $\mathrm{Na}^{+}$ was found to be lower in T2, T3, T4, and T8 relative to T1 in the case of 2 PV of water leaching. In $4 \mathrm{PV}$ leached soils, the concentration of $\mathrm{Na}^{+}$in $\mathrm{T} 5$ was $45.15 \%$ lower than that of $\mathrm{T} 1$.

The concentration of $\mathrm{Na}^{+}$in the leached soils was significantly lower $(\mathrm{p}<0.01)$ in all the treatments than in the NLS. The concentrations decreased by $14.07 \%$ and $80.87 \%$ due to the leaching of soils with 2 and 4 PV of water, respectively, compared with that under the non-leached condition. The leaching of the soils with $4 \mathrm{PV}$ of water resulted in a minimum of $61.31 \%$ decline in T1 and a maximum of $78.25 \%$ reduction in T5 compared with that of the soils with 2 PV.

The concentration of $\mathrm{Na}^{+}$in the leachates differed significantly $(\mathrm{p}<0.01)$ among the treatments (Figure 4b). The leachates contained as low as 2.12 times and as high as 2.48-fold $\mathrm{Na}^{+}$ concentration when the soils were leached with 4 PV of water compared with that when the leachates were collected after $2 \mathrm{PV}$ of water passed through the soils. The accumulation of $\mathrm{Na}^{+}$in the leachates was significantly high $(\mathrm{p}<0.01)$ when the soils were treated with amendments at high rates (Table 2).

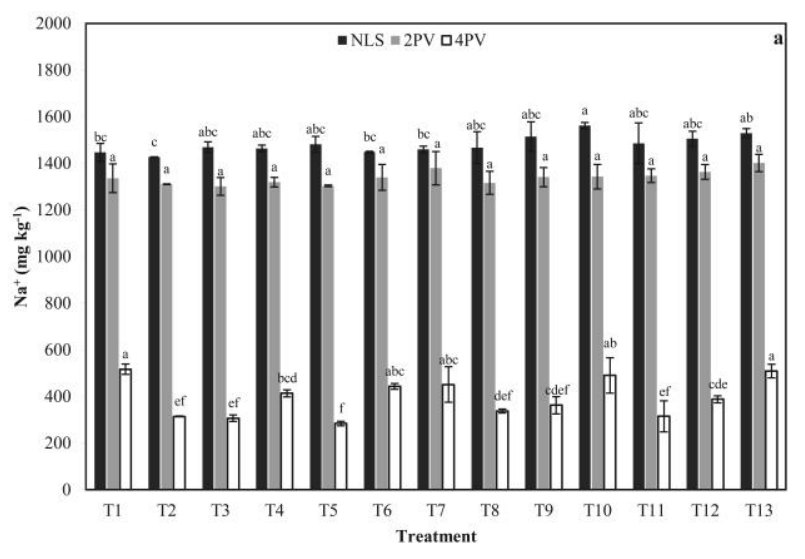

(a)

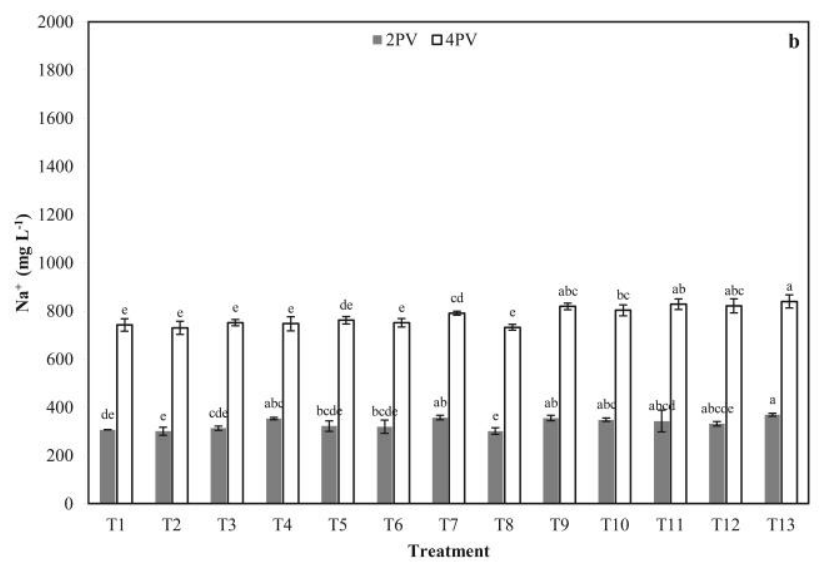

(b)

Figure 4. Concentration of $\mathrm{Na}^{+}$in (a) soils and (b) leachates under different treatments. Means followed by the same letter (s) among the same-colored bars did not differ significantly from each other at 5\% significance level

\subsection{The concentration of $K^{+}$in soils and leachates}

The concentration of $\mathrm{K}^{+}$was higher and statistically significant $(\mathrm{p}<0.01)$ in the organic and inorganic amended soils compared with that in control. Regardless of the variations in the quantity of leaching, WA either alone or in combination at 1 and $2 \mathrm{~g} 100 \mathrm{~g}^{-1}$ resulted in the high concentration of soil $\mathrm{K}^{+}$(Figure 5a). However, the concentrations increased as the rate of WA increased. In the NLS, the concentrations of $\mathrm{K}^{+}$in T3 and T9 were $115.78 \%$ and $204.61 \%$ higher than that of T1, respectively. When the soils were washed with $2 \mathrm{PV}$ of water, the concentrations of $\mathrm{K}^{+}$were $104.31 \%$ and $194.46 \%$ higher in T3 and T9 than that of T1, respectively. Similarly, the 
soils leached with $4 \mathrm{PV}$ of water had $97.06 \%$ and $149.75 \%$ higher concentrations of $\mathrm{K}^{+}$in $\mathrm{T} 3$ and $\mathrm{T} 9$ than that of T1. However, the maximum concentrations of $\mathrm{K}^{+}$were found in T13, i.e., $244.37 \%$, 231.36\%, and 204.08\% higher for non-leached, 2 PV, and 4 PV leached soils, respectively.

The concentrations of $\mathrm{K}^{+}$were lower in the leached soils of all the treatments than that in the NLS, and the rate was higher as the volume of water increased. With the exceptions of T1, T4 and T10, non-leached, 2 PV, and 4 PV leached soils significantly differed ( $p<0.01$ ). Leaching the soils with 2 and 4 PV of water resulted in maximum values of $14.95 \%$ and $37.14 \%$ reductions in $\mathrm{T} 8$ and minimum values of $2.89 \%$ and $8.89 \%$ in T1 compared with those in the NLS.

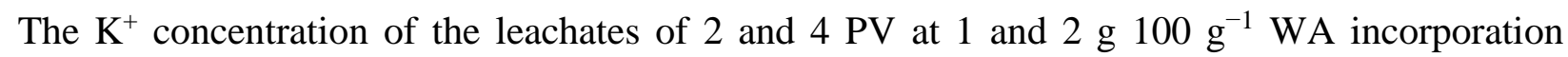
either alone or in combination were higher than that of T1(Figure $5 b$ ). The difference in the $\mathrm{K}^{+}$ concentration of the leachates among the treatments was statistically significant $(\mathrm{p}<0.01)$ under both leaching conditions. The maximum $\mathrm{K}^{+}$concentrations in the leachates were found in T11, i.e., $465.78 \%$ and $315.69 \%$ higher than that of T1 when the soils were leached with 2 and 4 PV of water, respectively. The accumulation of $\mathrm{K}^{+}$in leachates was also significantly higher $(\mathrm{p}<0.01)$ when the

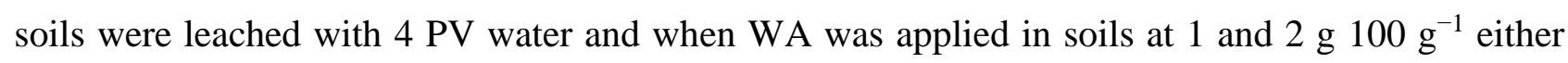
alone or in combination with other amendments (Table 2).

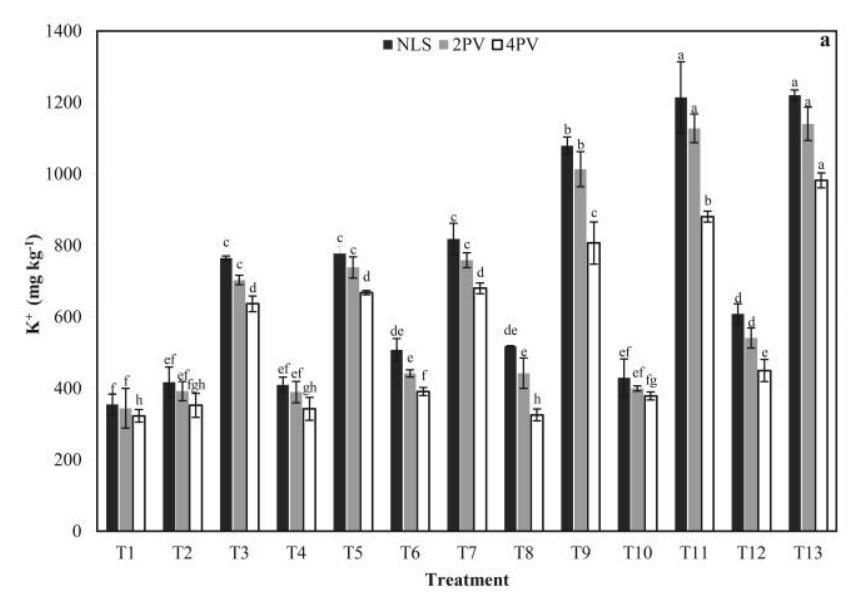

(a)

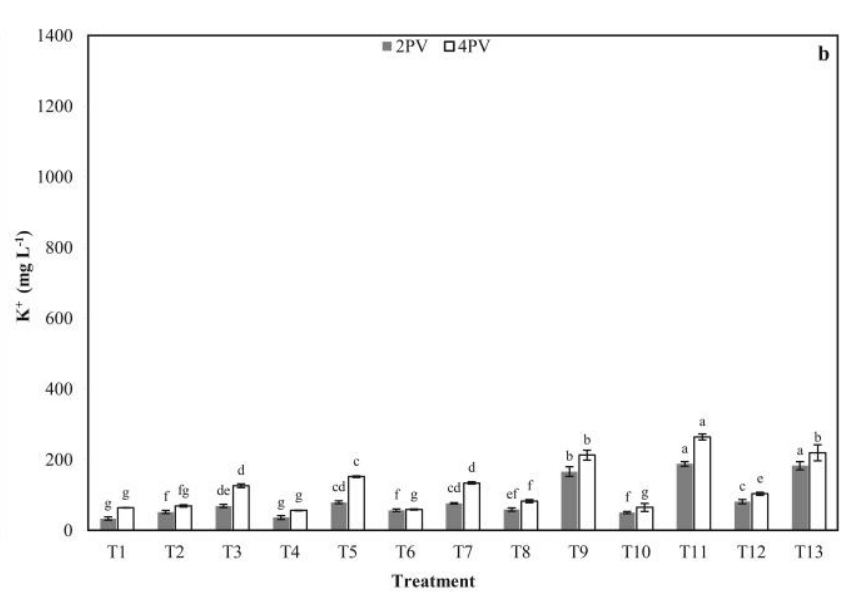

(b)

Figure 5. The concentration of $\mathrm{K}^{+}$in (a) soils and (b) leachates under different treatments. Means followed by the same letter (s) among the same-colored bars did not differ significantly from each other at 5\% significance level

\subsection{The concentration of $\mathrm{Ca}^{2+}$ in soils and leachates}

In Figure 6a, the incorporation of the amendments resulted in high $\mathrm{Ca}^{2+}$ concentrations in soils. The $\mathrm{Ca}^{2+}$ concentration was significantly lower $(\mathrm{p}<0.01)$ in $\mathrm{T} 1$ than in the amended soils except $\mathrm{T} 2$ in cases of NLS and $2 \mathrm{PV}$. Like the maximum $\mathrm{K}^{+}$concentration, the maximum $\mathrm{Ca}^{2+}$ concentration was found in the WA-treated soils applied either alone or in combination with other amendments. The 
concentration increased as the rate increased. When the soils were not allowed for leaching, T3 and T9 resulted in $152 \%$ and $180 \%$ more $\mathrm{Ca}^{2+}$ compared with that of $\mathrm{T} 1$. Conversely, when the soils were leached with 2 PV of water, the concentrations were $244.12 \%$ and $270.69 \%$ higher in T3 and T9 relative to $\mathrm{T} 1$, respectively. After the soils were leached with $4 \mathrm{PV}$ of water, the $\mathrm{Ca}^{2+}$ concentrations in T3 and T9 were $288.57 \%$ and $303.57 \%$ higher, respectively, compared to T1.

In NLS, the maximum $\mathrm{Ca}^{2+}$ concentration significantly varied $(\mathrm{p}<0.01)$ from all the other treatments was observed in T13. Likewise, the $\mathrm{Ca}^{2+}$ concentrations in 2 and $4 \mathrm{PV}$ were high in T13 followed by T11. These treatments did not differ significantly $(\mathrm{p}>0.01)$ from one another. The treatment T13 resulted in 214\%, 300\%, and 339\% more $\mathrm{Ca}^{2+}$ concentrations in the nonleached, 2 $\mathrm{PV}$, and $4 \mathrm{PV}$ leached soils than in T1, respectively.

The $\mathrm{Ca}^{2+}$ concentrations in the leachates were significantly high $(\mathrm{p}<0.01)$ in the WA-treated

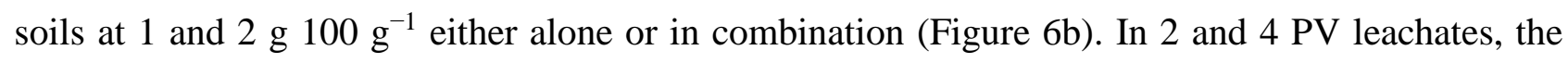
leachates' maximum concentrations were found $100 \%$ and $74.29 \%$ higher in T13 than in T1. By contrast, a minimum of $10 \%$ and $2.86 \%$ concentrations were observed in $\mathrm{T} 2$ compared to $\mathrm{T} 1$. Leaching the soils with $4 \mathrm{PV}$ yielded $146.59 \%$ more $\mathrm{Ca}^{2+}$ in the leachates than in the soils leached with 2 PV of water. The application of WA resulted in high $\mathrm{Ca}^{2+}$ accumulation in the leachates, and the accumulation level increased as the PV of water increased (Table 2).

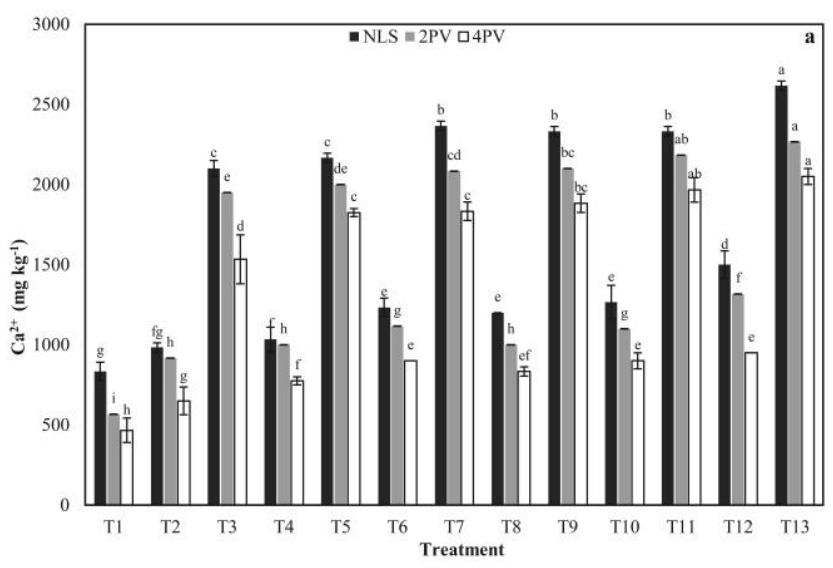

(a)

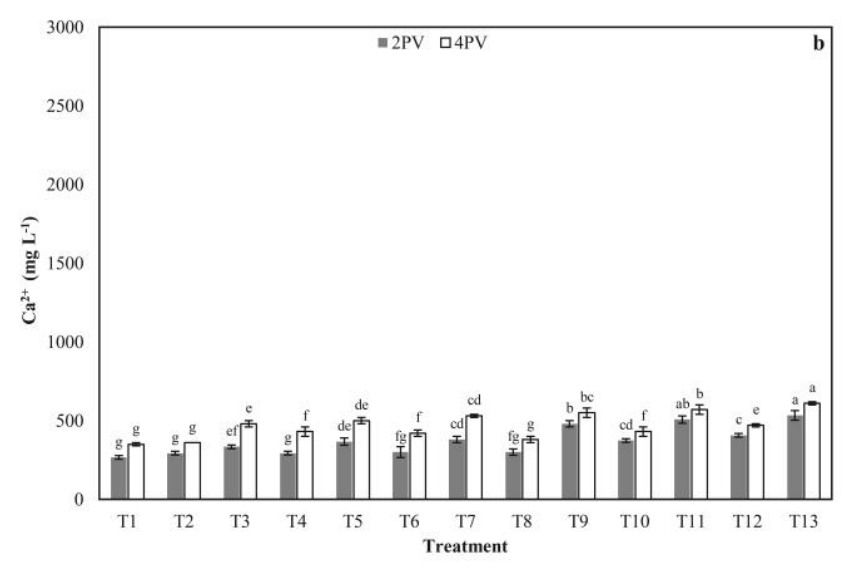

(b)

Figure 6. Concentration of $\mathrm{Ca}^{2+}$ in (a) soils and (b) leachates under different treatments. Means followed by the same letter (s) among the same-colored bars did not differ significantly from each other at $5 \%$ significance level

\subsection{The concentration of $\mathrm{Mg}^{2+}$ in soils and leachates}

The $\mathrm{Mg}^{2+}$ concentration was higher in the amended soils than in control (Figure 7a). In the NLS, the

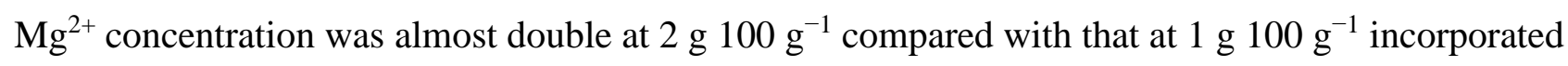
either individually or in combination. The concentrations of $\mathrm{Mg}^{2+}$ significantly differed $(\mathrm{p}<0.01)$ 
among the treatments in the NLS and 2 PV leached soils. In the NLS, the highest $\mathrm{Mg}^{2+}$ content was found in T11, i.e., it was $17.03 \%$ higher than T1 and significantly varied from that in the other treatments. When the amended soils were leached with $2 \mathrm{PV}$ of water, the highest $\mathrm{Mg}^{2+}$ concentration was observed in T5, i.e., $13.68 \%$ greater than that of T1.

Leaching resulted in significantly lower $(\mathrm{p}<0.01) \mathrm{Mg}^{2+}$ concentrations in the soils than in the NLS in the respective treatments. The concentrations of $\mathrm{Mg}^{2+}$ decreased by $20.21 \%$ and $43.30 \%$ compared with that in the NLS because of leaching with 2 and 4 PV of water, respectively. This finding was observed in $\mathrm{T} 11$ and $\mathrm{T} 4$. Conversely, the $\mathrm{Mg}^{2+}$ concentration in the soils declined by $4.12 \%$ in $\mathrm{T} 6$ and $22.22 \%$ in T1 because of 2 and 4 PV of water that leached through the soils.

When the concentration of $\mathrm{Mg}^{2+}$ in the leachates was analyzed, the maximum concentration was observed in T11, whereas the minimum value was detected in T1. The concentrations in T11 were $29.03 \%$ and $30.67 \%$ high in 2 and 4 PV leachates, respectively. The concentrations of $\mathrm{Mg}^{2+}$ in 2 and $4 \mathrm{PV}$ leachates were significantly different $(\mathrm{p}<0.01)$. The accumulation of $\mathrm{Mg}^{2+}$ in the leachates was higher in the soils treated with organic or inorganic amendments than in the control. The accumulation increased as the rate of amendments and PV of water increased (Table 2).

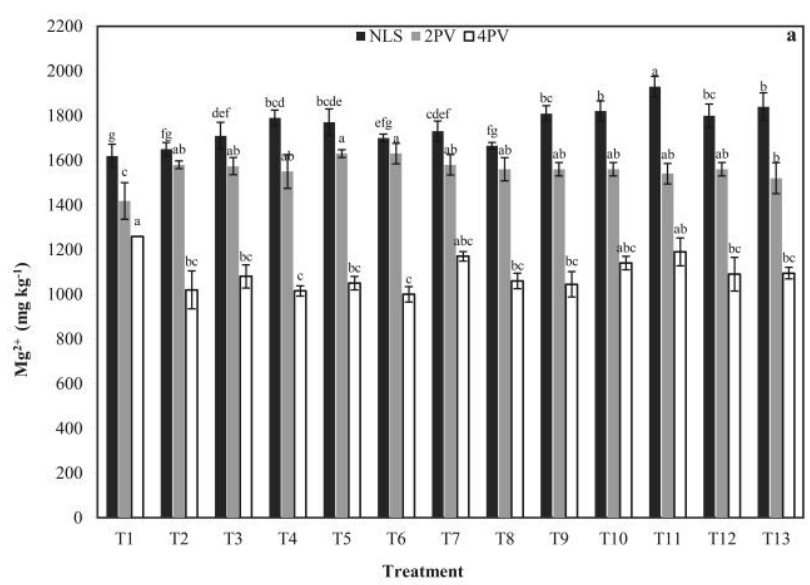

(a)

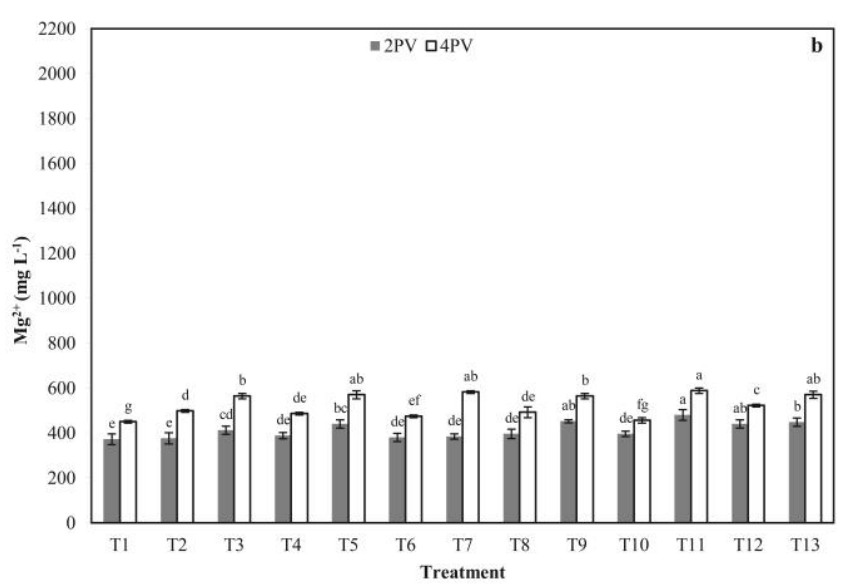

(b)

Figure 7. Concentration of $\mathrm{Mg}^{2+}$ in (a) soils and (b) leachates under different treatments. Means followed by the same letter (s) among the same-colored bars did not differ significantly from each other at $5 \%$ significance level

Table 2. Accumulation (mg) of $\mathrm{Na}^{+}, \mathrm{K}^{+}, \mathrm{Ca}^{2+}$, and $\mathrm{Mg}^{2+}$ in the leachates under different treatments.

\begin{tabular}{|c|c|c|c|c|c|c|c|c|}
\hline \multirow[t]{2}{*}{ Treatments } & \multicolumn{2}{|c|}{$\mathrm{Na}^{+}$} & \multicolumn{2}{|c|}{$\mathrm{K}^{+}$} & \multicolumn{2}{|c|}{$\mathrm{Ca}^{2+}$} & \multicolumn{2}{|c|}{$\mathrm{Mg}^{2+}$} \\
\hline & $2 \mathrm{PV}$ & $4 \mathrm{PV}$ & $2 \mathrm{PV}$ & $4 \mathrm{PV}$ & $2 \mathrm{PV}$ & $4 \mathrm{PV}$ & $2 \mathrm{PV}$ & $4 \mathrm{PV}$ \\
\hline T1 & $10.52^{\mathrm{de}}$ & $92.92^{\mathrm{ef}}$ & $1.14^{\mathrm{f}}$ & $7.95^{\mathrm{g}}$ & $9.16^{\mathrm{f}}$ & $43.87^{\mathrm{h}}$ & $12.77^{\mathrm{c}}$ & $56.40^{\mathrm{h}}$ \\
\hline $\mathrm{T} 2$ & $10.26^{\mathrm{e}}$ & $92.17^{\mathrm{ef}}$ & $1.76^{\mathrm{e}}$ & $8.70^{\mathrm{g}}$ & $10.02 \mathrm{e}^{\mathrm{f}}$ & $45.48^{\mathrm{h}}$ & $12.85^{\mathrm{c}}$ & $62.91^{\mathrm{e}}$ \\
\hline $\mathrm{T} 3$ & $10.53^{\mathrm{de}}$ & $91.65^{\mathrm{ef}}$ & $2.31^{\mathrm{d}}$ & $15.35^{\mathrm{d}}$ & $11.23^{\mathrm{e}}$ & $58.55^{\mathrm{f}}$ & $13.87^{\mathrm{c}}$ & $68.81^{\mathrm{c}}$ \\
\hline $\mathrm{T} 4$ & $12.41^{\mathrm{ab}}$ & $92.06^{\mathrm{ef}}$ & $1.26^{\mathrm{f}}$ & $6.89^{g}$ & $10.31^{\mathrm{ef}}$ & $53.02^{\mathrm{g}}$ & $13.65^{\mathrm{c}}$ & $59.94^{\mathrm{efg}}$ \\
\hline
\end{tabular}

DOI: https://doi.org/10.7454/jessd.v3i2.1075 


\begin{tabular}{|c|c|c|c|c|c|c|c|c|}
\hline \multirow[t]{2}{*}{ Treatments } & \multicolumn{2}{|c|}{$\mathrm{Na}^{+}$} & \multicolumn{2}{|c|}{$\mathrm{K}^{+}$} & \multicolumn{2}{|c|}{$\mathrm{Ca}^{2+}$} & \multicolumn{2}{|c|}{$\mathrm{Mg}^{2+}$} \\
\hline & $2 \mathrm{PV}$ & $4 \mathrm{PV}$ & $2 \mathrm{PV}$ & $4 \mathrm{PV}$ & $2 \mathrm{PV}$ & $4 \mathrm{PV}$ & $2 \mathrm{PV}$ & $4 \mathrm{PV}$ \\
\hline T5 & $11.09^{\text {bcde }}$ & $96.15^{\mathrm{de}}$ & $2.73^{c}$ & $19.14^{\mathrm{c}}$ & $12.64^{\mathrm{d}}$ & $63.17^{\mathrm{de}}$ & $15.18^{\mathrm{b}}$ & $72.02^{\mathrm{a}}$ \\
\hline T6 & $10.95^{\text {cde }}$ & $92.57^{\mathrm{ef}}$ & $1.94^{\mathrm{e}}$ & $7.23^{\mathrm{g}}$ & $10.31 \mathrm{e}^{\mathrm{f}}$ & $51.80^{\mathrm{g}}$ & $13.04^{c}$ & $58.46^{\mathrm{fgh}}$ \\
\hline $\mathrm{T} 7$ & $12.67^{\mathrm{a}}$ & $99.07^{\mathrm{cd}}$ & $2.70^{c}$ & $16.78^{\mathrm{d}}$ & $13.48^{\mathrm{cd}}$ & $66.42^{\mathrm{cd}}$ & $13.64^{c}$ & $72.95^{\mathrm{ab}}$ \\
\hline $\mathrm{T} 8$ & $10.52^{\mathrm{de}}$ & $91.01^{\mathrm{f}}$ & $2.04^{\mathrm{de}}$ & $10.23^{\mathrm{f}}$ & $10.47^{\mathrm{ef}}$ & $47.25^{\mathrm{h}}$ & $13.82^{\mathrm{c}}$ & $61.17^{\mathrm{ef}}$ \\
\hline T9 & $11.95^{\mathrm{abc}}$ & $100.94^{\mathrm{abc}}$ & $5.58^{\mathrm{b}}$ & $26.19^{b}$ & $16.15^{\mathrm{a}}$ & $67.84^{\mathrm{bc}}$ & $15.22^{\mathrm{b}}$ & $69.56^{\mathrm{bc}}$ \\
\hline T10 & $12.25^{\mathrm{abc}}$ & $100.27^{\mathrm{bcd}}$ & $1.76^{\mathrm{e}}$ & $8.07^{\mathrm{fg}}$ & $13.13^{\mathrm{cd}}$ & $53.74^{\mathrm{g}}$ & $13.93^{c}$ & $57.00^{\mathrm{gh}}$ \\
\hline T11 & $11.76^{\mathrm{abcd}}$ & $104.58^{\mathrm{ab}}$ & $6.44^{\mathrm{a}}$ & $33.35^{\mathrm{a}}$ & $17.40^{\mathrm{a}}$ & $71.99^{\mathrm{b}}$ & $16.48^{a}$ & $74.29^{\mathrm{a}}$ \\
\hline $\mathrm{T} 12$ & $11.37^{\text {abcde }}$ & $103.69^{\mathrm{abc}}$ & $2.78^{c}$ & $13.03^{\mathrm{e}}$ & $13.96^{\mathrm{c}}$ & $59.38^{\mathrm{ef}}$ & $15.11^{\mathrm{b}}$ & $65.95^{\mathrm{d}}$ \\
\hline $\mathrm{T} 13$ & $12.65^{\mathrm{a}}$ & $105.20^{\mathrm{a}}$ & $6.26^{\mathrm{a}}$ & $27.46^{\mathrm{b}}$ & $18.31^{\mathrm{a}}$ & $76.45^{\mathrm{a}}$ & $15.38^{\mathrm{b}}$ & $71.43^{\mathrm{abc}}$ \\
\hline $\begin{array}{l}\text { ANOVA } \\
\text { (P value) }\end{array}$ & 0.00 & 0.00 & 0.00 & 0.00 & 0.00 & 0.00 & 0.00 & 0.00 \\
\hline
\end{tabular}

Means followed by the same letter (s) among the treatments did not differ significantly from each other at 5\% significance level.

The correlation coefficients (r) of the different parameters of the NLS, 2 PV, and 4 PV leached soils are shown in Table 3, 4, and 5, respectively. In Table 3, the relationships of EC with that of $\mathrm{Na}^{+}, \mathrm{K}^{+}, \mathrm{Ca}^{2+}$, and $\mathrm{Mg}^{2+}$ were positive and significant $(\mathrm{p}<0.05)$ in the NLS. Conversely, in 2 and 4 PV leached soils, the relationships of EC with that of $\mathrm{Na}^{+}$were positive but not significant $(\mathrm{p}>$ 0.05 ), possibly because of the contribution of $\mathrm{Na}^{+}$and other cations (e.g., $\mathrm{K}^{+}$and $\mathrm{Ca}^{2+}$ ) in either increasing or lowering ECs.

Table 3. Correlation coefficients (r) among different parameters of NLS.

\begin{tabular}{lllllll}
\hline & $\mathrm{pH}$ & $\mathrm{EC}$ & $\mathrm{Na}^{+}$ & $\mathrm{K}^{+}$ & $\mathrm{Ca}^{2+}$ & $\mathrm{Mg}^{2+}$ \\
\hline $\mathrm{pH}$ & 1 & & & & & \\
$\mathrm{EC}$ & $0.718^{* *}$ & 1 & & & & \\
$\mathrm{Na}^{+}$ & 0.264 & $0.305^{*}$ & 1 & & & \\
$\mathrm{~K}^{+}$ & $0.924 * *$ & $0.664 * *$ & 0.263 & 1 & & \\
$\mathrm{Ca}^{2+}$ & $0.984 * *$ & $0.714^{* *}$ & $0.268^{*}$ & $0.915^{* *}$ & 1 & \\
$\mathrm{Mg}^{2+}$ & $0.562 * *$ & $0.671^{* *}$ & $0.373^{* *}$ & $0.621^{* *}$ & $0.534^{* *}$ & 1 \\
\hline
\end{tabular}

**Correlation is significant at the 0.01 level (one-tailed Pearson correlation)

* Correlation is significant at the 0.05 level (one-tailed Pearson correlation) 
Table 4. Correlation coefficients (r) among different parameters of 2 PV leached soils.

\begin{tabular}{lllllll}
\hline & $\mathrm{pH}$ & $\mathrm{EC}$ & $\mathrm{Na}^{+}$ & $\mathrm{K}^{+}$ & $\mathrm{Ca}^{2+}$ & $\mathrm{Mg}^{2+}$ \\
\hline $\mathrm{pH}$ & 1 & & & & & \\
$\mathrm{EC}$ & $0.332^{*}$ & 1 & & & & \\
$\mathrm{Na}^{+}$ & 0.159 & 0.196 & 1 & & & \\
$\mathrm{~K}^{+}$ & $0.934 * *$ & $0.440 * *$ & 0.202 & 1 & & \\
$\mathrm{Ca}^{2+}$ & $0.981^{* *}$ & $0.273 *$ & 0.188 & $0.920 * *$ & 1 & \\
$\mathrm{Mg}^{2+}$ & 0.183 & -0.249 & -0.108 & 0.010 & 0.228 & 1 \\
\hline
\end{tabular}

**Correlation is significant at the 0.01 level (one-tailed Pearson correlation)

* Correlation is significant at the 0.05 level (one-tailed Pearson correlation)

Table 5. Correlation coefficients (r) among different parameters of 4 PV leached soils.

\begin{tabular}{lllllll}
\hline & $\mathrm{pH}$ & $\mathrm{EC}$ & $\mathrm{Na}^{+}$ & $\mathrm{K}^{+}$ & $\mathrm{Ca}^{2+}$ & $\mathrm{Mg}^{2+}$ \\
\hline $\mathrm{pH}$ & 1 & & & & & \\
$\mathrm{EC}$ & $0.528^{* *}$ & 1 & & & & \\
$\mathrm{Na}^{+}$ & $-0.323^{*}$ & 0.165 & 1 & & & \\
$\mathrm{~K}^{+}$ & $0.911^{* *}$ & $0.683^{* *}$ & -0.093 & 1 & & \\
$\mathrm{Ca}^{2+}$ & $0.952^{* *}$ & $0.691 * *$ & -0.191 & $0.949 * *$ & 1 & \\
$\mathrm{Mg}^{2+}$ & -0.017 & 0.253 & $0.306^{*}$ & 0.120 & 0.012 & 1 \\
\hline
\end{tabular}

**Correlation is significant at the 0.01 level (1-tailed Pearson correlation)

* Correlation is significant at the 0.05 level (1-tailed Pearson correlation)

\subsection{Yield of plant}

The response of plants under nonbleached and leached soils was evaluated in terms of yield parameters. From the trial pot experiment, no seeds were germinated in the nonbleached pot soils. The yield parameters of the plants grown in the soils leached with $2 \mathrm{PV}$ of water are shown in Figure 8.

The leaching of soils in the presence of different amendments remarkably changed the $\mathrm{pH}, \mathrm{EC}$, $\mathrm{Na}^{+}, \mathrm{K}^{+}, \mathrm{Ca}^{2+}$, and $\mathrm{Mg}^{2+}$ of soils and leachates. In addition, the application of amendments to the NLS significantly changed the physicochemical properties of soils. The $\mathrm{pH}$ of saline soils is nearly neutral or slightly alkaline. In the present study, the collected soil sample was acidic in nature. The acidic nature of saline soils in different parts of the coastal areas in Bangladesh was also observed by other authors (Chowdhury, 2016; Haque, 2018; Jamil et al., 2020). In the present study, the acidic nature of saline soils could be ascribed to the dominance of $\mathrm{SO}_{4}{ }^{2-}$ (e.g., $530.83 \pm 5.30 \mathrm{mg}$ DOI: https://doi.org/10.7454/jessd.v3i2.1075 
$\mathrm{kg}^{-1}$ ) and $\mathrm{Cl}^{-}$(e.g., $627.17 \pm 5.12 \mathrm{mg} \mathrm{kg}^{-1}$ ) as the associated anions of $\mathrm{Na}^{+}$. When $\mathrm{SO}_{4}{ }^{2-}$ dominates over $\mathrm{Cl}^{-}$in saline soils, the $\mathrm{pH}$ declines correspondingly. Similar observations were reported by other authors (Gunarathne et al., 2020 and Li et al., 2006).

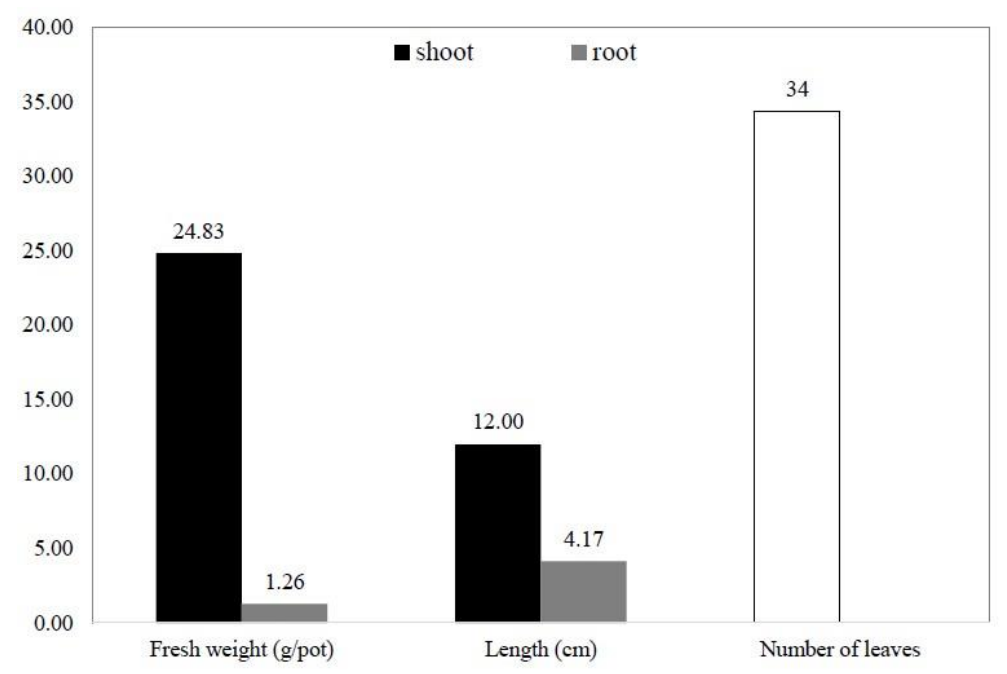

Figure 8. Yield parameters of plants

Regardless of the types and rates of amendments, leaching increased the $\mathrm{pH}$ of soils as the leaching amount increased, possibly because $\mathrm{SO}_{4}{ }^{2-}$ was washed out as leaching increased. The higher $\mathrm{pH}$ of soils amended either with organic or inorganic amendments was consistent with previous findings (Mkhabela \& Warman, 2005; Ouni et al., 2013; Tejada et al., 2006; Wang et al., 2014; Wu, et al., 2014). On the other hand, Chaganti et al. (2015) found no significant differences in $\mathrm{pH}$ when anthracite coal powder-treated soils were subjected to leaching. The application of WA significantly increases the soil $\mathrm{pH}$, and this observation was consistent with other studies (GómezRey et al., 2012; Ohno \& Erich, 1990; Saarsalmi et al., 2004). The increase in the pH of the amended soils compared with that of the control might be the direct contribution of amendments through releasing alkaline components. Similar observations were reported by Yu et al. (2015). Mkhabela and Warman (2005) also reported that the increase in $\mathrm{pH}$ in organic amended soils can be attributed to the release of basic cations, such as $\mathrm{K}^{+}, \mathrm{Ca}^{2+}$, and $\mathrm{Mg}^{2+}$, and the production of $\mathrm{OH}^{-}$by ligand exchange.

The EC of the amended and nonamended soils decreased as the PV of water increased. This finding agreed with that of Kahlon et al. (2013). However, the extent of salt removal through leaching depends on the nature and amount of salt, initial EC, expected EC after leaching, depth of soil to be reclaimed, soil properties (especially texture, structure, infiltration, and permeability), quality and quality of water for leaching, methods and frequency of water application, and other DOI: https://doi.org/10.7454/jessd.v3i2.1075 
factors (Abrol et al., 1988; Rhoades, 1982). Soils containing large amounts of fine fractions usually require more water to remove the same amount of salts from soils having a high amount of coarse fractions (Gaines \& Gaines, 1994; Hoseini \& Delbari, 2015). Regardless of leaching, the incorporation of organic and inorganic amendments increased soil EC, and this observation was consistent with other findings (Ouni et al., 2013; Roy \& Kashem, 2014; Wang et al., 2014).

The high ECs of WA-amended soils and their leachates were likely due to the high EC of WA compared with that of VC and zeolite. Moreover, the high ECs of the soils and leachates at high rates of incorporation compared with those at low doses might be due to the presence of high amounts of $\mathrm{Ca}^{2+}, \mathrm{Mg}^{2+}$, and $\mathrm{K}^{+}$in amendments (Leogrande \& Vitti, 2019; Wang et al., 2014). Ding et al. (2020) and Yu et al. (2015) reported that the response of EC to organic amendments depends on the rate and duration of the incorporation of amendments.

The lower content of $\mathrm{Na}^{+}$in the amended soils than in the control receiving $4 \mathrm{PV}$ of water could be attributed to the higher release of $\mathrm{K}^{+}$and $\mathrm{Ca}^{2+}$ from the amendments, which displaced more $\mathrm{Na}^{+}$ from the exchange sites of soils. A similar result was found by Chaganti et al. (2015). The decrease in $\mathrm{Na}^{+}$in the amended and nonamended soils with the increasing volume of water could be due to the increasing solubility and the displacement of $\mathrm{Na}^{+}$from the exchange sites and its subsequent washing out with percolating water through leaching. Several authors reported a high amount of $\mathrm{Na}^{+}$leaching with an increasing volume of irrigation (Oo et al., 2015; Qadir \& Oster, 2004). However, the high concentration of $\mathrm{Na}^{+}$in soils treated with WA and zeolite in combination under leaching and nonleaching conditions could be ascribed to the added $\mathrm{Na}^{+}$from these amendments. A considerable amount of $\mathrm{Na}^{+}$in soils was also found when the soils were treated with zeolite (AlBusaidi et al., 2008).

The significantly high concentrations of $\mathrm{Mg}^{2+}$ and exchangeable $\mathrm{K}^{+}$and $\mathrm{Ca}^{2+}$ before and after the leaching of the soils treated with organic amendments could be due to the inherent concentrations of these elements. Several authors reported a significant increase in $\mathrm{Ca}^{2+}, \mathrm{Mg}^{2+}$, and $\mathrm{K}^{+}$in soils treated with WA (Demeyer et al., 2001; Füzesi et al., 2015; Ohno \& Erich, 1990). Chaganti et al. (2015) observed higher concentrations of exchangeable $\mathrm{Ca}^{2+}$ in initial and post-leaching saline-sodic soils amended with different organic amendments, such as biochar, bio-solid compost, and green waste composts than that in the control. The higher $\mathrm{WA}-\mathrm{Ca}^{2+}:$ control- $\mathrm{Ca}^{2+}$ ratio of soils despite the increasing leaching might be a reason of a divalent character that results in the slow release of $\mathrm{Ca}^{2+}$ from WA-amended soils. Walker and Bernal (2008) also observed the saturation of the exchange sites of soils mainly with $\mathrm{Ca}^{2+}, \mathrm{Mg}^{2+}$, and $\mathrm{K}^{+}$in saline soils amended with organic amendments. The higher concentrations of $\mathrm{Na}^{+}, \mathrm{K}^{+}, \mathrm{Ca}^{2+}$, and $\mathrm{Mg}^{2+}$ in leachates with increasing PV of water were 
consistent with the findings of Hussain et al. (2016), i.e., the concentrations of these cations significantly increased in the leachates as the amount of irrigation water increased. However, irrigation water quality should be considered in the reclamation of saline soils through soluble salts' leaching. In most cases, irrigation water in coastal areas either from surface or underground sources contains considerable $\mathrm{Na}+$ and $\mathrm{Cl}$, which may worsen the prevailing soil salinity (Roy et al., 2020; Spark, 2002).

High soil salinity adversely affected seed germination, and this finding agreed with that of Panuccio et al. (2014). Wu et al. (2015) also found that salt stress inhibits seed germination and seedling emergence and affects the length of roots and shoots and the fresh and dry weights of plants. Leaching is an effective approach to reclaim and restore the productivity of saline soils. The removal of salts, especially $\mathrm{Na}^{+}$, through leaching and the concomitant decrease in EC before plants were grown was effective in seed germination and plant growth. Khoshgoftarmanesh et al. (2003) similarly demonstrated that the addition of more water than that required by barley before planting declines soil salinity and increases plant yield.

\section{Conclusion}

Salinity in the leached soils decreased compared with that in the NLS. As leaching progressed, the soil EC in all the treatments decreased, whereas the leachate EC increased. Moreover, VC, WA, and zeolite served as important sources of cations, especially $\mathrm{K}^{+}$and $\mathrm{Ca}^{2+}$, thereby limiting the entry of $\mathrm{Na}^{+}$into the exchange complex and facilitating leaching with percolating water. The removal of salts through leaching and the concomitant decrease in EC before plants grew were effective in seed germination and plant growth. Thus, experimental results provided further insights into saline soil management through the integrative approaches of leaching and amendment application for crop production's long-term planning. However, some facts should be considered in reclaiming saline soils.

The application of irrigation water can contribute to a significant loss of valuable nutrients such as $\mathrm{K}^{+}, \mathrm{Ca}^{2+}$, and $\mathrm{Mg}^{2+}$, consequently affecting their turnover in saline soils. The quality of irrigation water is another concern because poor-quality irrigation can worsen soil salinity problems in saltaffected areas. Though our research answered several questions regarding the reclamation of saline soils through the application of organic and inorganic amendments under varying water contents, further studies should address some research questions on the effectiveness of leaching on saline soil reclamation and plant growth under different organic and inorganic amendments through greenhouse and field experiments. 


\section{Acknowledgement}

The present work is a part of the research project financed by Research and Publication Cell, University of Chittagong (Grant No. 6760/Res/Con/Pub/Cell/C.U/2019). The authors also acknowledge the Department of Soil Science, the University of Chittagong for all kinds of laboratory facilities.

\section{Author Contribution}

Sajal Roy and Nasrin Chowdhury conceived of the presented idea. Sajal Roy developed the theory and performed the computations. Sajal Roy and Nasrin Chowdhury verified the analytical methods. Nasrin Chowdhury encouraged Sajal Roy to investigate the reclamation of saline soil and supervised the findings of this work. All authors discussed the results and contributed to the final manuscript.

\section{References}

Abrol, I. P., Yadav, J. S. P., \& Massoud F. I. (1988). Salt affected soils and their management. FAO soils bulletin 39. Rome: Food and Agriculture Organization of the United Nations.

Alam, S. M. (1999). Nutrient uptake by plants under stress conditions. In: M. Pessarakli (Ed), Handbook of plant and crop stress (pp. 285-313). New York, USA: Marcel Dekker, Inc.

Al-Busaidi, A., Yamamoto, T., Inoue, M., Eneji, A.E., Mori, Y., \& Irshad, M. (2008). Effects of zeolite on soil nutrients and growth of barley following irrigation with saline water. Journal of Plant Nutrition, 31(7), 1159-1173. https://doi.org/10.1080/01904160802134434

Amouei, A. I., Yousefi, Z., \& Khosravi, T. (2017). Comparison of vermicompost characteristics produced from sewage sludge of wood and paper industry and household solid wastes. Journal of Environmental Health Science \& Engineering, 15(5). https://doi.org/10.1186/s40201-017-0269-z

Ayers, R. S., \& Westcot, D. W. (1985). Water quality for agriculture. FAO Irrigation and Drainage Paper. 29 Rev. 1. Food and Agriculture Organization of the United Nations, Rome. https://www.researchgate.net/profile/Abdelkader_Bouaziz/post/I_am_looking_for_a_research _paper/attachment/5e934607f155db0001f47f0a/AS\%3A879539731316736\%4015867100218 48/download/Water+Quality+for+Agriculture.pdf 
Boh M. Y., Müller, T., \& Sauerborn, J. (2013). Maize (Zea mays L.) response to urine and wood ash fertilization under saline $(\mathrm{NaCl})$ soil conditions. International Journal of AgriScience, 3(4), 333-345.

http://www.inacj.com/attachments/section/17/Temp\%20April\%202012776\%20Michael\%20Yongha\%20Boh\%20F\%20P\%20(333-345).pdf

Brady, N. C., \& Weil, R. R. (2005). The nature and properties of soils, 13th ed. Delhi, India: Pearson-Prentice Hall.

Chaganti, V. N., Crohn, D. M., \& Simunek, J. (2015). Leaching and reclamation of a biochar and compost amended saline-sodic soil with moderate SAR reclaimed water. Agricultural Water Management, 158, 255-265. https://doi.org/10.1016/j.agwat.2015.05.016

Chapman, H. (1965). Cation exchange capacity. In: C. Black (Ed), Methods of soil analysis (pp. 891-901). Madison, Wisconsin, USA: American Society of Agronomy. https://acsess.onlinelibrary.wiley.com/doi/abs/10.2134/agronmonogr9.2.c6

Chowdhury, N. (2016). Influence of rice straw incorporation on the microbial biomass and activity in coastal saline soils of Bangladesh. Open Journal of Soil Science, 6(10), 159-173. http://dx.doi.org/10.4236/ojss.2016.610016

Demeyer, A., Nkana, J. C. V., \& Verloo, M. G. (2001). Characteristics of wood ash and influence on soil properties and nutrient uptake: An overview. Bioresource Technology, 77(3), 287-295. https://doi.org/10.1016/S0960-8524(00)00043-2

Ding, Z., Kheir, A. M. S., Ali, M. G. M., Ali, O. A. M., Abdelaal, A. I. N., Lin, X., Zhou, Z., Wang, B., Liu, B., \& He, Z. (2020). The integrated effect of salinity, organic amendments, phosphorus fertilizers, and deficit irrigation on soil properties, phosphorus fractionation and wheat productivity. Scientific Reports, 10, 2736. https://doi.org/10.1038/s41598-020-59650-8

Doula, M. K., \& Sarris, A. (2016). Soil environment. In: S.G. Poulopoulos, V.J. Inglezakis (Eds), Environment and development: Basic principles, human activities, and environmental implications (pp. 213-286). London, UK: Academic Press. https://doi.org/10.1016/B978-0444-62733-9.00004-6

Etesami, H., \& Noori, F. (2019). Soil salinity as a challenge for sustainable agriculture and bacterial-mediated alleviation of salinity stress in crop plants. In: M.M. Kumar, H. Etesami, V. Kumar (Eds), Saline soil-based agriculture by halotolerant microorganisms (pp. 1-22). Springer Singapore. https://doi.org/10.1007/978-981-13-8335-9_1 
Füzesi, I., Heil, B., \& Kovács, G. (2015). Effects of wood ash on the chemical properties of soil and crop vitality in small plot experiments. Acta Silvatica et Lignaria Hungarica, 11(1), 5564. https://www.researchgate.net/deref/http\%3A\%2F\%2Fdx.doi.org\%2F10.1515\%2Faslh2015-0004

Gaines, T. P., \& Gaines, S. T. (1994). Soil texture effect on nitrate leaching in soil percolates. Communications in Soil Science and Plant Analysis, 25(13-14), 2561-2570. https://doi.org/10.1080/00103629409369207

Gómez-Rey, M. X., Madeira, M., \& Coutinho, J. (2012). Wood ash effects on nutrient dynamics and soil properties under Mediterranean climate. Annals of Forest Science, 69(5), 569-579. http://dx.doi.org/10.1007\%2Fs13595-011-0175-y

Gull, A., Lone, A.A., \& Wani, N.U.I. (2019). Biotic and abiotic stresses in plants. In: A.B. de Oliveira (Ed), Abiotic and biotic stress in plants (pp. 1-6). London, UK: IntechOpen.

Gunarathne, V., Senadeera, A., Gunarathne, U., Biswas, J. K., Almaroai, Y. A., \& Vithanage, M. (2020). Potential of biochar and organic amendments for reclamation of coastal acidic-salt affected soil. Biochar, 2, 107-120. https://link.springer.com/content/pdf/10.1007/s42773-02000036-4.pdf

Haque, M. A. (2018). Variation in salinity through the soil profile in south coastal region of Bangladesh. Journal of Bangladesh Academy of Sciences, 42(1), 11-23. https://doi.org/10.3329/jbas.v42i1.37829

Hardie, M., \& Doyle, R. (2012). Measuring soil salinity. In: S. Shabala, T.A. Cuin (Eds), Plant salt tolerance: Methods and protocols, methods in molecular biology (pp. 415-425). Totowa, NJ: Humana Press. https://doi.org/10.1007/978-1-61779-986-0_28

Harker, D. B., \& Mikalson, D. E. (1990). Leaching of a highly saline-sodic soil in Southern Alberta: A laboratory study. Canadian Journal of Soil Science, 70, 509-514. https://doi.org/10.4141/cjss90-051

Hoseini, E. S., \& Delbari, M. (2015). Column leaching experiments on saline soils of different textures in Sistan plain. Desert, 20(2), 207-215. https://www.sid.ir/en/journal/ViewPaper.aspx?id=508301

Huq, S. M. I., \& Alam, M. D. (2005). A handbook on analysis of soil, plant and water. Bangladesh, BACER-DU: University of Dhaka. https://www.scirp.org/(S(vtj3fa45qm1ean45vvffcz55))/reference/ReferencesPapers.aspx?Refe renceID $=2345392$ 
Hussain, Z., Khattak, R. A., Irshad, M., Mahmood, Q., \& An, P. (2016). Effect of saline irrigation water on the leachability of salts, growth and chemical composition of wheat (Triticum aestivum L.) in saline-sodic soil supplemented with phosphorus and potassium. Journal of Soil Science and Plant Nutrition, 16(3), 604-620. http://dx.doi.org/10.4067/S071895162016005000031

Jamil, M. R., Kabir, M. H., Chowdhury, M. N., Islam, M. T., \& Islam, M. S. (2020). Seasonal changes of soil salinity and nutrients in the coastal Bhola Island, Bangladesh. Bangladesh Journal of Environmental Science, 39, 5-12. https://www.academia.edu/download/64358976/BJES_39_2020_5-

12_Soil\%20salinity\%20and\%20nutrients\%20in\%20coastal\%20Bhola\%20isand.pdf

Kahlon, U. Z., Murtaza, G., Murtaza, B., \& Hussain, A. (2013). Different response of soil texture for leaching of salts receiving different pore volumes of water in saline-sodic soil column. Pakistan Journal of Agricultural Sciences, 50(2), 191-198. https://www.osti.gov/etdeweb/biblio/22188048

Khan, M. A., \& Duke, N. C. (2001). Halophytes-A resource for the future. Wetland Ecology and Management, 6, 455-456. https://www.halophyte.org/pdfs/drkhan_pdfs/87.pdf

Khoshgoftarmanesh, A. H., Shariatmadari, H., \& Vakil, R. (2003). Reclamation of saline soils by leaching and barley production. Communications in Soil Science and Plant Analysis, 34(1920), 2875-2883. https://doi.org/10.1081/CSS-120025198

Kirkham, M. B. (2004). Principles of soil and plant water relations. London, UK: Academic Press.

Leogrande, R., \& Vitti, C. (2019). Use of organic amendments to reclaim saline and sodic soils: A review. Arid Land Research and Management, 33(1), 1-21. https://doi.org/10.1080/15324982.2018.1498038

Li, X., Li, F., Singh, B., Cui, Z., \& Rengel, Z. (2006). Decomposition of maize straw in saline soil. Biology and Fertility of Soils, 42, 366-370. https://doi.org/10.1007/s00374-005-0042-9

Mkhabela, M., \& Warman, P. R. (2005). The influence of municipal solid waste compost on yield, soil phosphorus availability and uptake by two vegetable crops, grown in a Pugwash sandy loam soil in Nova Scotia. Agriculture, Ecosystem \& Environment, 106(1), 57-67. https://doi.org/10.1016/j.agee.2004.07.014

Mostafazadeh-Fard, B., Heidarpour, M., Aghakhani, A., \& Feizi, M. (2008). Effects of leaching on soil desalinization for wheat crop in an arid region. Plant, Soil and Environment, 54(1), 2029. https://agris.fao.org/agris-search/search.do?recordID=CZ2008000349 
Nelson, D. W., \& Sommers, L. E. (1982). Total carbon, organic carbon and organic matter. In: A. L. Page, R. H. Miller \& Keeney (Eds), Methods of soil analysis: Chemical and microbiological properties (pp. 539-579). Madison, Wisconsin, USA: American Society of Agronomy, Inc. Soil Science Society of America, Inc. https://acsess.onlinelibrary.wiley.com/doi/abs/10.2134/agronmonogr9.2.2ed.c29

Ohno, T., \& Erich, M. S. (1990). Effect of wood ash application on soil pH and soil test nutrients levels. Agriculture, Ecosystems and Environment, 32, 223-239. https://doi.org/10.1016/01678809(90)90162-7

Oo, A. N., Iwai, C. B., \& Saenjan, P. (2015). Soil properties and maize growth in saline and nonsaline soils using cassava-industrial waste compost and vermicompost with or without earthworms. Land Degradation and Development, 26(3), 300-310. https://doi.org/10.1002/ldr.2208

Ouni, Y., Lakhdar, A., Scelza, R., Scotti, R., Abdelly, C., Barhoumi, Z., \& Rao, M. A. (2013). Effects of two composts and two grasses on microbial biomass and biological activity in a salt-affected soil. Ecological Engineering, 60, 363-369. https://doi.org/10.1016/j.ecoleng.2013.09.002

Panuccio, M. R., Jacobsen, S. E., Akhtar, S. S., \& Muscolo, A. (2014). Effect of saline water on seed germination and early seedling growth of the halophyte quinoa. AoB PLANTS, 6, plu047. https://doi.org/10.1093/aobpla/plu047

Parkinson, J. A., \& Allen, S. E. (1975). A wet oxidation procedure suitable for the determination of nitrogen and mineral nutrients in biological material. Communications in Soil Science and Plant Analysis, 6(1), 1-11. https://doi.org/10.1080/00103627509366539

Premanandarajah, P. (2017). Combined effect of organic manure and leaching on soil salinity, nitrate availability and ground water quality. International Journal of Research in Environmental Science, 3(4), 24-28. https://pdfs.semanticscholar.org/9b11/478f18b5c587a86799194dd566a9afad43c0.pdf

Qadir, M., \& Oster, J. D. (2004). Crop and irrigation management strategies for saline-sodic soils and waters aimed at environmentally sustainable agriculture. Science of the Total Environment, 323, 1-19. https://doi.org/10.1016/j.scitotenv.2003.10.012

Qadir, M., Schubert, S., \& Steffens, D. (2005). Phytotoxic substances in soils. In: D. Hillel (Ed), Encyclopedia of soils in the environment (pp. 216-222). London, UK: Academic Press. https://cgspace.cgiar.org/handle/10568/37421 
Ramulu, U. S. S. (2003). Principles in the quantitative analysis of waters, fertilizers, plants and soils. India: Scientific Publishers. https://www.cabdirect.org/cabdirect/abstract/20043147961

Rhoades, J. D. (1982). Reclamation and management of salt-affected soils after drainage. Proc. First. Ann. Western Provincial Conf. Rationalization of Water and Soil Research and Management. Lethbridge, Alberta, Canada, 29 Nov.-2 Dec. 1982. pp. 123-197. https://ci.nii.ac.jp/naid/10019602670/

Roy, S., \& Chowdhury, N. (2020a). Salt stress in plants and amelioration strategies: A critical review. London, UK: IntechOpen. https://www.intechopen.com/online-first/salt-stress-inplants-and-amelioration-strategies-a-critical-review

Roy, S., \& Chowdhury, N. (2020b). Salt affected soils: Diagnosis, genesis, distribution and problems. In P. K. Naresh (Ed.), Advances in agriculture sciences (pp. 111-132). India: AkiNik Publications. https://www.akinik.com/publishbookchapter/154770824524-advancesin-agriculture-sciences

Roy, S., \& Kashem, M. A. (2014). Effects of organic manures in changes of some soil properties at different incubation periods. Open Journal of Soil Science, 4(3), 81-86. https://doi.org/10.4236/ojss.2014.43011

Roy, S., Akhtaruzzaman, M., \& Nath, B. (2020). Spatio-seasonal variations of salinity and associated chemical properties in the middle section of Karnaphuli River water, Chittagong, Bangladesh using laboratory analysis and GIS technique. International Journal of Environmental Science and Development, 11(8), 372-382. http://www.ijesd.org/vol11/1278IJESD-457.pdf

Roy, S., Kashem, M. A., \& Osman, K. T. (2018). The uptake of phosphorous and potassium of rice as affected by different water and organic manure management. Journal of Plant Sciences, 6(2), 31-40.

Saarsalmi, A., Mälkönen, E., \& Kukkola, M. (2004). Effect of wood ash fertilization on soil chemical properties and stand nutrient status and growth of some coniferous stands in Finland. Scandinavian Journal of Forest Research, 19(3), 217-233.

https://doi.org/10.1080/02827580410024124

Spark, D. L. (2002). Environmental soil chemistry. 2nd ed. UK: Academic Press, London.

SRDI (2010). Saline soils of Bangladesh. Ministry of Agriculture, Government of the People's Republic of Bangladesh, Dhaka, Bangladesh. 
Tejada, M., Garcia, C., Gonzalez, J. L., \& Hernandez, M. T. (2006). Use of organic amendment as a strategy for saline soil remediation: Influence on the physical, chemical and biological properties of soil. Soil Biology and Biochemistry, 38(6), 1413-1421. https://doi.org/10.1016/j.soilbio.2005.10.017

Uddin, M. S., Khan, M. S. I., Talukdar, M. M. R., Hossain, M. I., \& Ullah, M. H. (2011). Climate change and salinity in Bangladesh: Constraints and management strategy for crop production. Rajshahi University Journal of Environmental Science, 1, 11-16. https://www.researchgate.net/publication/266225315_Climate_change_and_salinity_in_Bangl adesh_Constraints_and_management_strategy_for_crop_production

Walker, D. J., \& Bernal, M. P. (2008). The effects of olive mill waste compost and poultry manure on the availability and plant uptake of nutrients in a highly saline soil. Bioresource Technology, 99(2), 396-403. https://doi.org/10.1016/j.biortech.2006.12.006

Wang, L., Sun, X., Li, S., Zhang, T., Zhang, W., \& Zhai, P. (2014). Application of organic amendments to a coastal saline soil in North China: Effects on soil physical and chemical properties and tree growth. PLoS ONE, 9(2), e89185.

https://doi.org/10.1371/journal.pone.0089185

Wicke, B., Smeets, E., Dornburg, V., Vashev, B., Gaiser, T., Turkenburg, W., \& Faaij, A. (2011). The global technical and economic potential of bioenergy from salt-affected soils. Energy \& Environmental Science, 4, 2669-2681. https://doi.org/10.1039/C1EE01029H

Wilke, B. M. (2005). Determination of chemical and physical soil properties. In R. Margesin, F. Schinner (Eds.), Manual for soil analysis-Monitoring and assessing soil bioremediation (pp. 47-95), Springer-Verlag Berlin Heidelberg. https://doi.org/10.1007/3-540-28904-6_2

Wu, G. Q., Jiao, Q., \& Shui, Q. Z. (2015). Effect of salinity on seed germination, seedling growth, and inorganic and organic solutes accumulation in sunflower (Helianthus annuus L.). Plant, Soil and Environment, 61, 220-226. https://doi.org/10.17221/22/2015-PSE

Wu, Y., Xu, G., Lv, Y. C., \& Shao, H. B. (2014). Effects of Biochar Amendment on Soil Physical and Chemical Properties: Current Status and Knowledge Gaps. Advances in Earth Science, 29(1), 68-79. http://ir.yic.ac.cn/handle/133337/6871

Yu, Y., Liu, J., Liu, C., Zong, S., \& Lu, Z. (2015). Effect of organic materials on the chemical properties of saline soil in the Yellow River Delta of China. Frontiers in Earth Science, 9(2), 259-267. https://doi.org/10.1007/s11707-014-0463-6 
Yue, Y., Guo, W. N., Lin, Q. M., Li, G. T., \& Zhao, X. R. (2016). Improving salt leaching in a simulated saline soil column by three biochars derived from rice straw (Oryza sativa L.), sunflower straw (Helianthus annuus), and cow manure. Journal of Soil and Water Conservation, 71(6), 467-475. https://doi.org/10.2489/jswc.71.6.467

Zhang, Z. J., Wang, X. Z., Wang, H., Huang, E., Sheng, J. L., Zhou, L. Q., \& Jin, W. Z. (2020). Housefly larvae (Musca domestica) vermicompost on soil biochemical features for a Chrysanthemum (Chrysanthemum morifolium) farm. Communications in Soil Science and Plant Analysis, 51(10), 1315-1330. https://doi.org/10.1080/00103624.2020.1763389 